CTMI (2007) 315:363-388

(C) Springer-Verlag Berlin Heidelberg 2007

\title{
Ebolavirus and Other Filoviruses
}

\author{
J. P. Gonzalez ${ }^{1}(\bowtie) \cdot$ X. Pourrut ${ }^{1} \cdot$ E. Leroy ${ }^{1}$
}

${ }^{1}$ Fundamentals and Domains of Disease Emergence Research Unit, RU178, Institute for Research Development, IRD, Paris, France frjpg@mahidol.ac.th

Introduction

Ebola Virus and Hosts

A Variety of Incidental Hosts and an Elusive Reservoir

Animal Species Affected by Ebola Virus ...................................................... 368

Toward Understanding a Complex Natural Cycle and the Origin of Primate Ebola Epidemics

Other Members of the Filovirus Family....

4.2 The Phylogeographic Enigma of Reston Virus......................................... 378

$5 \quad$ Conclusions ........................................................................................... 379

5.1 Bats, an Underappreciated Reservoir Host for Zoonotic Viruses.................. 379

5.2 Bats and Human Disease Emergence........................................................ 380

5.3 Intraspecies and Interspecies Contact and the Risk of Epidemic Initiation.. 382

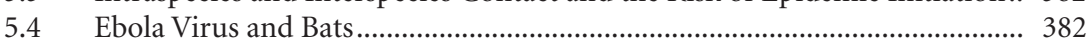

$5.5 \quad$ Research Perspectives............................................................................ 384

References

Abstract Since Ebola fever emerged in Central Africa in 1976, a number of studies have been undertaken to investigate its natural history and to characterize its transmission from a hypothetical reservoir host(s) to humans. This research has comprised investigations on a variety of animals and their characterization as intermediate, incidental, amplifying, reservoir, or vector hosts. A viral transmission chain was recently unveiled after a long absence of epidemic Ebola fever. Animal trapping missions were carried out in the Central African rain forest in an area where several epidemics and epizootics had occurred between 2001 and 2005. Among the various animals captured and analyzed, three species of fruit bats (suborder Megachiroptera) were found asymptomatically and naturally infected with Ebola virus: Hypsignathus monstrosus (hammer-headed fruit beats), Epomops franqueti (singing fruit bats), and Myonycteris torquata (little collared fruit bats). From experimental data, serological studies and virus genetic analysis, these 
findings confirm the importance of these bat species as potential reservoir species of Ebola virus in Central Africa. While feeding bats drop partially eaten fruit and masticated fruit pulp (spats) to the ground, possibly promoting indirect transmission of Ebola virus to certain ground dwelling mammals, if virus is being shed in saliva by chronically and asymptomatically infected bats. Great apes and forest duikers are particularly sensitive to lethal Ebola virus infection. These terrestrial mammals feed on fallen fruits and possibly spats, suggesting a chain of events leading to Ebola virus spillover to these incidental hosts. This chain of events may occur sporadically at different sites and times depending on a combination of the phenology of fruit production by different trees, animal behavior, and various, but as yet still unknown environmental factors, which could include drought. During the reproductive period, infected body fluid can also be shed in the environment and present a potential risk for indirect transmission to other vertebrates.

\section{1}

\section{Introduction}

In 1976, two geographically isolated epidemics of viral hemorrhagic fever of unknown etiology occurred in Africa, each accompanied by mortality exceeding 50\%. The etiological agent causing the outbreaks was found to be a new virus, named Ebola virus. The Ebola virus, together with Marburg virus, a virus of African geographic origin which had been recognized less than 10 years earlier (Martini and Siegert 1971), were subsequently defined as the prototype viruses of a new taxonomic family, Filoviridae (Kiley et al. 1982). This name reflects the very unusual morphology of virions observed by electron microscopy, that of a thread or filament (Latin: filum; thread). The Filoviridae virus family belongs to the order of Mononegavirales characterized by genetic material carried by only one thread of RNA with negative polarity.

Since the emergence of Ebola fever in 1976, many studies have been undertaken to determine the transmission chain of Ebola virus from a hypothetical animal reservoir to humans. This included the search and identification of possible hosts, their characterization as intermediate, incidental and/or amplifying hosts or reservoirs, and finally the search for one or more potential vectors (Monath 1999; Feldmann et al. 2004). This chapter describes the elements of the viral transmission chain, which was described recently after an absence of epidemic activity of Ebola fever for more than 20 years in the specific locales studied. The findings implicate several animal species as playing a central role in the natural maintenance cycle of Ebola virus and in the pathway leading to viral emergence among humans. This pathway involves viral propagation and amplification 
within the reservoir host and subsequent transmission to intermediate or incidental host(s) capable of sustaining a high incidence of infection accompanied by a high viremia.

\section{2}

\section{Ebola Virus and Hosts}

\section{1}

\section{A Variety of Incidental Hosts and an Elusive Reservoir}

Due to the nature of its emergence in central Africa, often in areas of inadequate medical infrastructure, studies on Ebola virus have focused on epidemic emergence or resurgence. Intensive research on the origin of this devastating and elusive virus was recently undertaken to find one or more, if any, of its reservoirs. After the first epidemic of 1976 in an area between South Sudan and North Zaire, 3,200 vertebrates and 30,000 insects were collected and tested for the presence of Ebola virus, but no reservoir was identified (Johnson 1976; Arata et al. 1977).

Although a few animal species in Central Africa have been identified with low titers of antibody reactive with Ebola virus antigens, it is only recently that conclusive evidence of active infection with Ebola virus in any wildlife species has been obtained (Table 1). Technological advances in viral diagnostic methods (ELISA, antigen captures, PCR, immunohistochemical labeling of Ebola virus antigens in specific tissues) have made it possible for recent surveys to employ highly sensitive and specific tools to screen for potential reservoir species for zoonotic viruses in ways unavailable to prior investigators (see the chapter by Daniels et al., this volume). Molecular biological methods also permit phylogenetic reconstruction of ancestral viral lineages using sequence data obtained from multiple viral strains isolated at different times; investigators can characterize viruses without isolating each strain and produce models of potential transmission pathways and direction (see the chapter by Holmes and Drummond, this volume). Additionally, prior surveys were conducted during interepidemic phases when there was little or no evidence of Ebola virus activity. During the epidemic outbreaks of Ebola virus occurring between 2001 and 2004 in Gabon and the Republic of Congo, many dead animals were found in the tropical forest areas affected by the epidemic (Leroy et al. 2004). During the 2001-2004 epidemic, 44 carcasses of wild animals were discovered, permitting necropsies to be performed and tissue samples to be collected; samples were transported and analyzed at the high-security laboratory of the Medical Research Centre of Franceville (CIRMF), in Gabon. Sixteen animals (12 gorillas, three chimpanzees, and a 
Table 1 Research on the host and reservoir of African Ebola virus

\begin{tabular}{|c|c|c|c|c|c|}
\hline Host type & Test $^{\mathrm{a}}$ & Habitat & $\begin{array}{l}\text { Positive/ } \\
\text { total }\end{array}$ & Origin & Date $^{\mathrm{b}}$ \\
\hline \multicolumn{6}{|l|}{ Shrew } \\
\hline Sylvisorex ollula & IFA & $\mathrm{F}$ & $1 / 10$ & CAR & 1999 \\
\hline \multicolumn{6}{|l|}{ Rodents } \\
\hline Arvicanthis spp. & IFA & S & $9 / 98$ & CAR & $1979-1983$ \\
\hline Mastomys spp. & IFA & $\mathrm{F}$ & $2 / 91$ & CAR & $1979-1983$ \\
\hline Mastomys spp. & IFA & S & $10 / 265$ & CAR & $1979-1983$ \\
\hline Mus spp. & IFA & F & $2 / 54$ & CAR & $1979-1983$ \\
\hline Praomys spp & ELISA & $\mathrm{F}$ & $1 / 41$ & & 1999 \\
\hline \multicolumn{6}{|l|}{ Bats } \\
\hline Hypsignathus monstrosus & ELISA & F & $8 / 32$ & Gabon, RC & $2002-2003$ \\
\hline Epomops franquetti & ELISA & $\mathrm{F}$ & $4 / 102$ & Gabon, RC & 2002-2003 \\
\hline Myonycteris torquata & ELISA & $\mathrm{F}$ & $4 / 58$ & Gabon, RC & 2002-2003 \\
\hline \multicolumn{6}{|l|}{ Other mammals } \\
\hline Cattle & IFA & S & $2 / 108$ & CAR & $1979-1983$ \\
\hline Chicken & IFA & $S$ & $13 / 131$ & CAR & $1979-1983$ \\
\hline Dog & IFA & $\mathrm{F}$ & $26 / 1162$ & CAR & 1979-1983 \\
\hline Donkey & IFA & S & $3 / 13$ & CAR & 1979-1983 \\
\hline Pig & IFA & F & $13 / 80$ & CAR & 1979-1983 \\
\hline Dog & ELISA & $\mathrm{F}$ & $55 / 258$ & Gabon & 2002 \\
\hline \multicolumn{6}{|l|}{ Nonhuman primates } \\
\hline Cercopithecus spp. & ELISA & F & $1 / 107$ & $\begin{array}{l}\text { Cameroon, } \\
\text { Gabon, RC }\end{array}$ & 1980-2002 \\
\hline Papio spp. & ELISA & F & $1 / 25$ & $\begin{array}{l}\text { Cameroon, } \\
\text { Gabon, RC }\end{array}$ & 1980-2002 \\
\hline Mandrillus spp. & ELISA & $\mathrm{F}$ & $6 / 215$ & $\begin{array}{l}\text { Cameroon, } \\
\text { Gabon, RC }\end{array}$ & 1980-2002 \\
\hline Gorilla gorilla & ELISA & F & $2 / 30$ & $\begin{array}{l}\text { Cameroon, } \\
\text { Gabon, RC }\end{array}$ & 1980-2002 \\
\hline Pan troglodytes & ELISA & F & $29 / 225$ & $\begin{array}{l}\text { Cameroon, } \\
\text { Gabon, RC }\end{array}$ & 1980-2002 \\
\hline
\end{tabular}

The data presented here are limited to serologic investigations partly done in the Congolese basin rain forest of Central Africa of the Ebola virus enzootic domain (i.e., not including Sudan and Ivory Coast zones which are in different geographical domains). Only animal types with Ebola-Zaire positive antibodies are listed; for more detail please refer to Pourrut et al. 2005; Morvan et al. 2000; Gonzalez et al. 2005

$F$ Forest; $S$ Savannah; CAR Central African Republic; $R C$ Republic of Congo

${ }^{a}$ IFA $>1: 128$, ELISA = screening serum dilution dogs 1:400, nonhuman primates 1:100, bats 1:50

bYear of collection 
forest duiker) were found positive, by one or more diagnostic test, for Ebola virus infection (E. Leroy, personal communication), demonstrating natural infection and mortality caused by Ebola virus among three species of wildlife. Calculations of relative population size, based on indices of animal presence and abundance in specific locales (excrement, tracks, broken vegetation, nests, etc.), revealed a significant rise in mortality (decline in population size) among certain animal species immediately before and during epidemics of human disease. The populations of gorillas and duikers fell by half between 2002 and 2003 in the Lossi sanctuary $\left(320 \mathrm{~km}^{2}\right)$, Republic of Congo, and the estimated population size of chimpanzees fell by $88 \%$. Even if these results are approximations (since it is known, for example, that the disappearance of a dominating adult male gorilla causes the break-up of the group and that the dispersed individuals are then difficult to count), they suggested that localized epidemics of Ebola virus can cause significant mortality among certain wildlife species in a very short period of time (Fig. 1). These results complement observations obtained from other studies indicating that significant reductions in populations of gorillas and chimpanzees in the areas of Gabon occur coincidentally with Ebola epidemics affecting humans (Huijbregts et al 2003; Walsh et al. 2003). A previous study conducted in the Taï forest of the Ivory Coast indicated that 11 members of a group of 43 chimpanzees disappeared (a reduction of $26 \%$ of the group) during November 1994 when Ebola virus was affecting humans (Formenty et al. 1999).

Sequences of the glycoprotein (GP) gene coding region of the of Ebola virus (the gene considered to be the most variable in Ebola virus genome), obtained from viral RNA extracted from tissue samples obtained from the carcasses of gorillas and chimpanzees, showed that these dead animals were infected by different viral strains. These results indicate that infection of these large primates resulted from simultaneous but independent infections, acquired from an animal reservoir favoring certain environmental conditions (Leroy et al. 2004a). The presence of antibody among chimpanzees sampled before the onset of the first epidemic of Ebola in this area suggests Ebola virus transmission had been occurring prior to the detection of fatal cases (Leroy et al. 2004b).

Observations of the spatial distribution of Ebola virus infection among great ape populations, coupled with reconstruction of the phylogenetic relatedness of viral sequences recovered from different locations, have led to mathematical modeling of the likely spread of Ebola virus. Viral transmission and disease among apes and humans appears to have spread as an epidemic wavefront, originating from a single epidemic epicenter defined by the zone affected by the first Ebola epidemic of 1976 in the Democratic Republic of Congo (RDC), in a northwestern, southeastern direction (Walsh et al. 2003, 2005). 

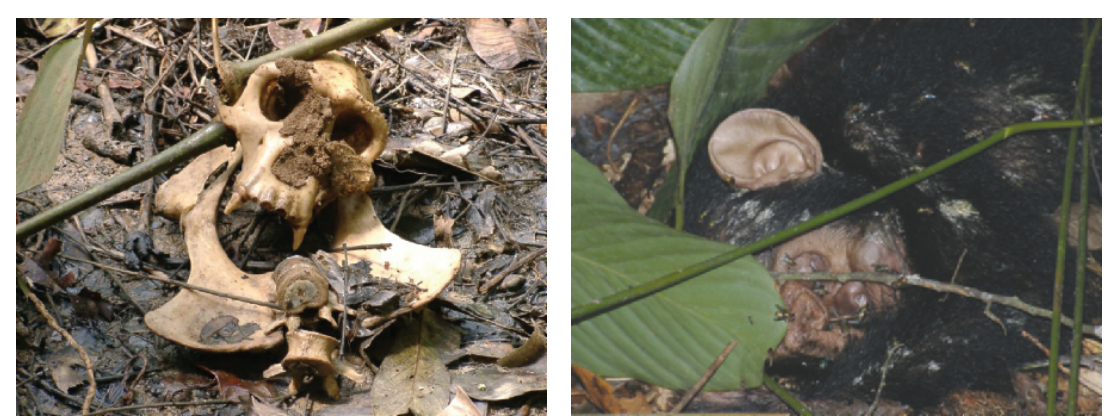

A

B
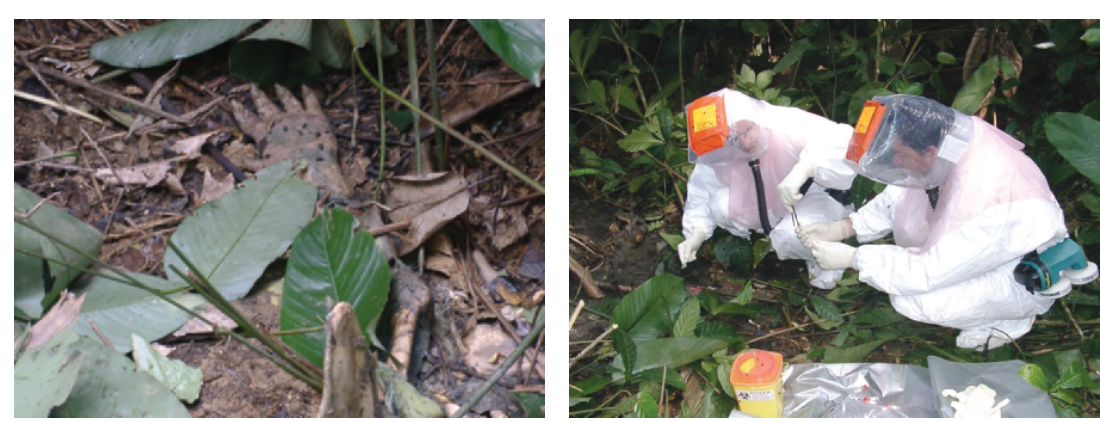

C

D

Fig. 1 Victims of the Ebola virus. Carcasses of nonhuman primates infected by Ebola virus discovered in the forest of Gabon and the Republic of Congo. Genetic sequences of the virus were detected in bone tissues (a cranium of chimpanzee found approximately 3 weeks after its death), in the skin or the muscle (b hand of gorilla found 2 weeks after death of the animal), and in the liver and the spleen (corpse of dead chimpanzee 3-4 days before harvest)

\section{2}

\section{Animal Species Affected by Ebola Virus}

A serologic survey testing 790 samples from 20 species of primates sampled from Cameroon, Gabon, and Republic of Congo (RC), found the prevalence of anti-Ebola IgG, or antibodies reactive to Ebola virus antigens, among chimpanzees to be $12.9 \%$ (Leroy et al. 2004b). The results suggested that chimpanzees are in regular contact with the Ebola virus reservoir(s) or infectious virus released into their environment and that some individuals experience nonlethal infections. Furthermore, these data indicate that infection by Ebola virus is ongoing among wildlife during quiescent phases of epidemic disease 
in humans; Ebola virus may have been enzootic in the forested regions of central Africa for an extended period of time. The presence of anti-Ebola-specific antibodies in other primate species, including five drills (Papio leucophaeus), a Western baboon (Papio papio), a mandrill (Papio sphinx), and a Cercopithecus sp., suggests that the circulation of the virus could be much more complex than the simple passage from reservoir to gorillas and chimpanzees. It has been hypothesized that several reservoir species for Ebola virus may exist and epidemiological and virological findings indicate that direct contact with incidentally infected intermediate hosts, such as gorillas and chimpanzees, can lead to sporadic cases and outbreaks of Ebola fever among humans. Additionally, molecular biological data indicate that genetically diverse strains of Ebola virus circulate in nature and can cause fatal disease among wildlife and humans; the potential existence of Ebola virus variants of reduced virulence offers an attractive hypothesis to explain the existence of anti-Ebola specific antibodies among primates.

In addition to Ebola virus spillover to wildlife, domestic dogs have been exposed to and become infected by Ebola virus, as determined by serological studies. At the time of the last Ebola epidemics in Gabon and RC, several dogs were observed consuming the remains of animals fatally infected by Ebola virus. Although the dogs failed to develop any visible clinical signs of disease (Allela et al. 2005), a study undertaken in Gabon after the 2001-2002 epidemics identified anti-Ebola IgG antibodies among dogs; the prevalence of antibodies increased significantly with the proximity of the sample site to the epidemic focus. The prevalence of antibodies to Ebola virus in dogs ranged from $9 \%$ in the two largest cities in Gabon, to $15 \%$ in the largest town of the epidemic zone, to $25 \%$ in rural villages without identifiable human cases, and reached $32 \%$ in villages with human Ebola cases directly linked to contact with an infected animal source (Allela et al. 2005). The potential for dogs to survive infection by Ebola virus requires experimental follow-up and, if documented, the potential for infected dogs to shed Ebola virus; by which routes for what duration of time requires elucidation. If domestic dogs prove to be a potential source of human infection the finding could offer one explanation for human epidemics where the original source of exposure has proved elusive.

One can conclude from the above-described investigations and findings that several different taxonomic orders of wild and domestic mammals can be found infected by one or more viral variants of Ebola during epidemics of human disease. Furthermore, there is evidence of ongoing Ebola virus transmission from reservoir host to incidental hosts during interepidemic phases. As the geographic range and preferred habitat of many of the species harboring antibody overlaps, the direction and relative frequency of virus transmission among diverse hosts cannot 


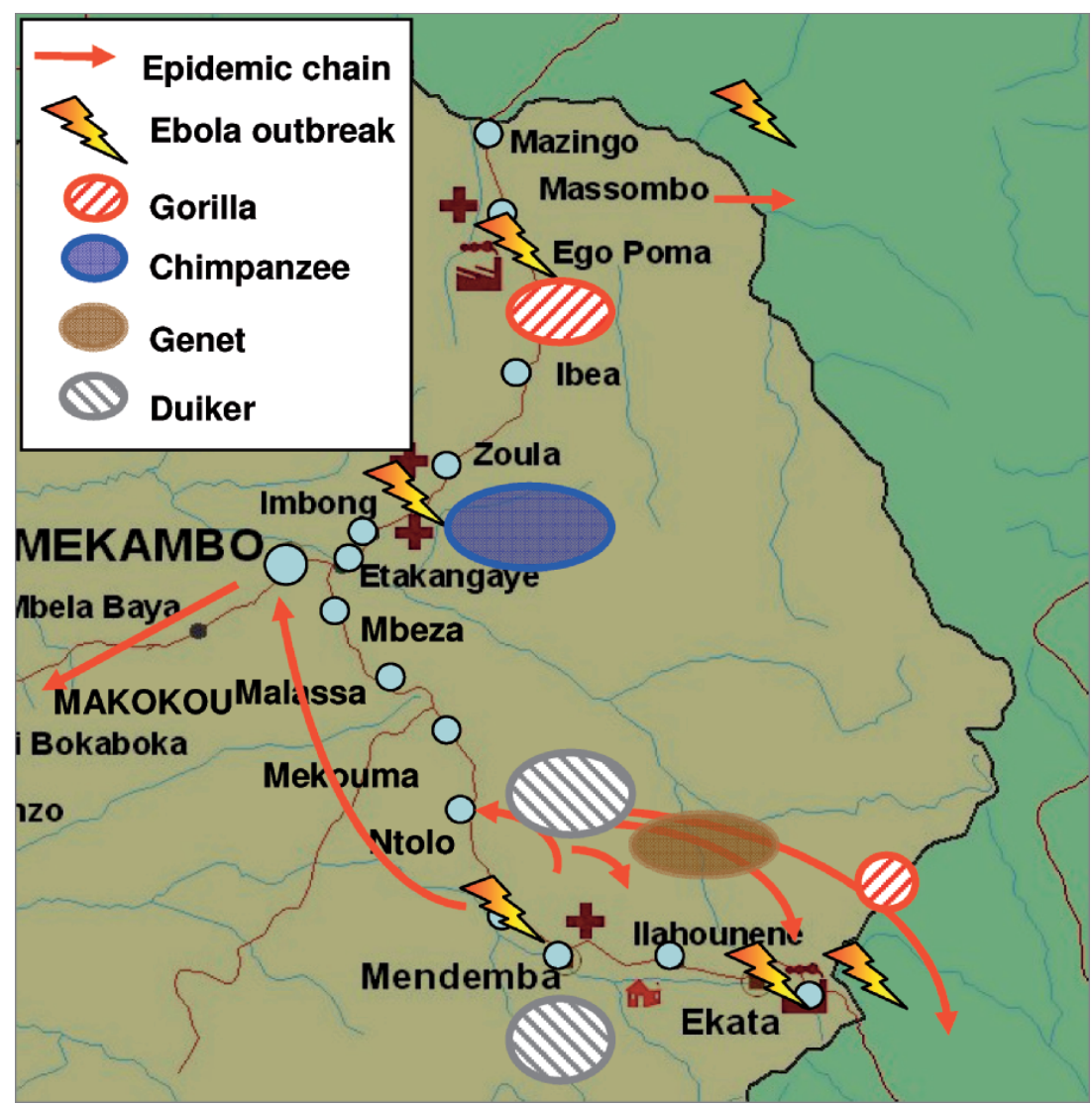

Fig.2 Areas where infected animals were found during epidemics in Gabon. Territories (circles) where infected animals were found are overlapping and thus show the complexity of virus transmission, which can exist between virus host reservoirs, intermediate hosts, or accidental hosts. Red circles gorilla; blue circles chimpanzee; black circles Duikers; brown circles Genetta (genets)

be deciphered at the present. Clarifying the individual contribution of incidental hosts in a transmission chain leading to human disease or to a maintenance cycle of different virus variants remains an important, but challenging, endeavor (Fig. 2).

2.3

The Discovery of an Elusive Host: Ebola Virus Reservoirs in Africa

Since 1976, many studies have aimed to identify silently infected but otherwise healthy animal carriers of Ebola virus, but without success (Johnson 
1978; Arata and Johnson 1978; Heymann et al. 1980; Gonzalez et al. 1983; Breman et al. 1999; Reiter et al. 1995; Leirs et al. 1999; Formenty et al. 1999). However, analyses carried out on specimens taken from 242 mammals (24 bats, 163 rodents, and 56 insectivorous shrews) captured in the Central African Republic (RCA) in 1998 identified partial Ebola virus genetic sequences in six mice (Mus setulosus and Praomys sp.) and a shrew (Sylvisorex ollula) (Morvan et al. 1999). The absence of a specific serological response, together with the absence of amplifiable total viral sequences, the failure to isolate virus, the nonreproducibility of the results, and the absence of epidemiologic indices favoring the potential role of these animals in Ebola virus epidemics, meant that it was not possible to confirm that these animals were reservoirs of Ebola virus.

Three surveys were recently completed, which targeted the collection of small and medium-sized mammals inhabiting the two forest belts surrounding villages affected by the Ebola epidemics occurring between 2001 and 2005 (Leroy et al. 2005). Animal trapping was initiated a few days after the carcass of an Ebola-infected gorilla was discovered and was limited to the area within $10 \mathrm{~km}$ of the carcass site. Over a 3-week period, 1,030 animals were captured and autopsied to obtain tissues for analysis; the laboratory analyses were performed over 4 years (Leroy et al. 2005).

Anti-Ebola IgG was detected in the serum of 16 bats including four Hypsignathus monstrosus, eight Epomops franqueti, and four Myonycteris torquata; no other species of bat or other mammal was seropositive (Fig. 3). Similarly, viral nucleic acid sequences were detected in the tissues from 13 bats; three $H$. monstrosus, five E. franqueti, and five $M$. torquata with overlapping domains (Fig. 4) and behavior (Fig. 5). Nucleotide sequences were identified and confirmed as fragments of Ebola virus genes; phylogenetic analyses by Bayesian methods and maximum parsimony identified the greatest similarity was to Ebola virus subtypes found in Zaire (Fig. 6). Although no Ebola virus isolates were obtained, the findings from this study constitute the first virological and biological evidence that certain megachiropteran fruit bats serve as principal reservoir hosts for Ebola virus. Epidemiologic findings collected during previous epidemics suggest contact with fruit bats is relatively common, as these species are a source of bushmeat and the geographic range of the putative reservoir species overlay the known areas of epidemic disease. Additionally, previous studies have documented that a transitory viremia occurs in certain bat species following experimental infection with the Ebola virus (Pourrut et al. 2005; Bergman 1999; Swanepoel et al. 1996). Together, field and experimental findings indicate the plausibility of the hypothesis that certain species of bat serve as the principal reservoir host for at least some variants of Ebola virus. 

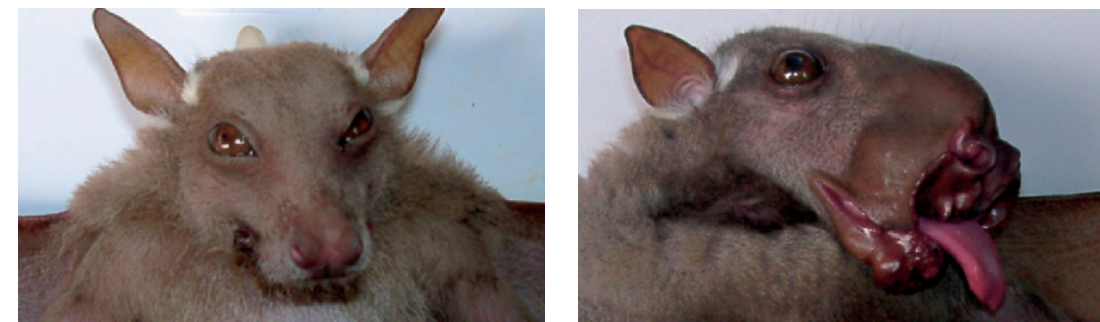

A

B

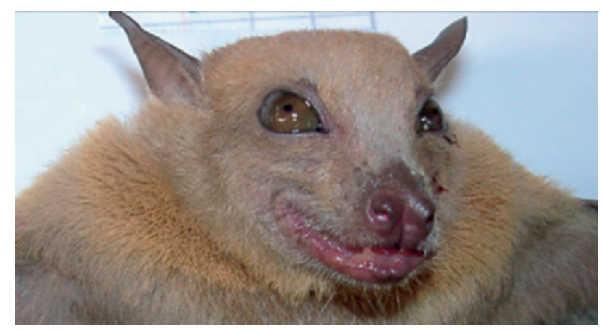

C

Fig. 3 Three bat species believed to be potential reservoirs of Ebola virus. Photographs of the three species of bats that are potential hosts of Ebola virus: Hypsignathus monstrosus (hammer-headed fruit bat), Epomops franqueti (singing fruit bat), and Myonycteris torquata (little collared fruit bat). These bats are found in the forested areas of central Africa. They have been recorded from Senegal to northern Angola and prefer riverine forests, swamps, mangroves, and palm forests. They play an important role as pollinators of flowers and in dispersing seeds. Their diet consists of fruits, leaves, flowers, nectar, and pollen. H. montrosus is the largest bat found in Africa, with males, whose heads are greatly enlarged, significantly larger than females. These three species are nocturnal, roosting during the day in groups of five to 20

It is interesting to note that megachiropteran fruit bats are also reservoirs of Hendra (Halpin et al. 2000) and Nipah (Yob et al. 2001) viruses of the Paramyxoviridae family, and Microchiroptera bats are the probable ancestors of all rabies virus variants, serotype 1/genotype 1 of the genus Lyssavirus in the family Rhabdoviridae, now infecting terrestrial mammals (Badrane and Tordo 2001; Amengal et al. 1997). The Paramyxoviridae and Rhabdoviridae are the other viral families in the order Mononegavirales and are genetically closely related to the Filoviridae (Monath 1999). 


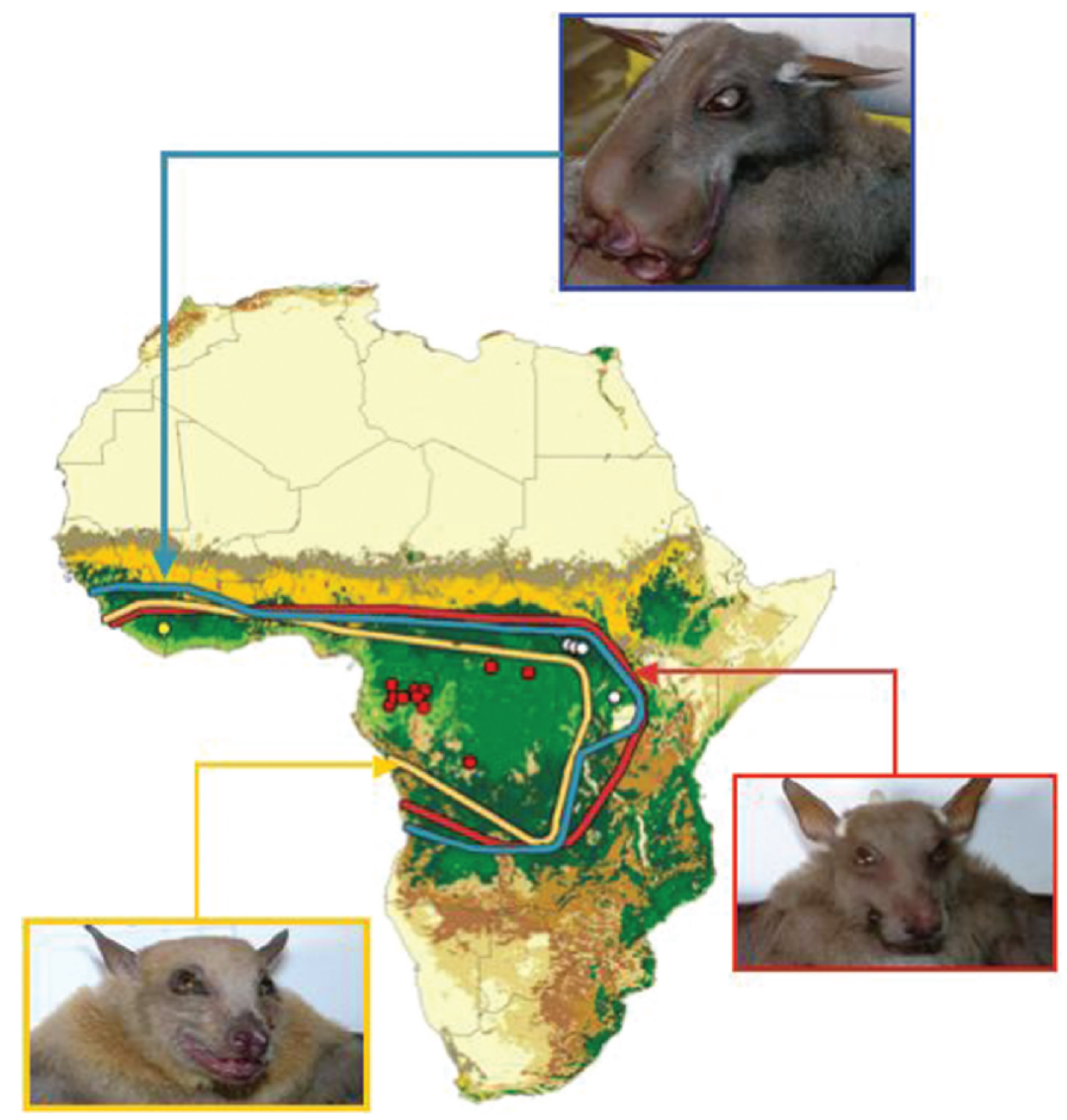

Fig. 4 Distribution of the three bat species that are potential reservoirs of Ebola virus. The colored lines mark the limits of distribution of each species (blue Hypsignathus monstrosus; red Epomops franqueti; yellow Myonycteris torquata). It is important to note that the habitats of each species overlap totally

\section{3}

\section{Toward Understanding a Complex Natural Cycle and the Origin of Primate Ebola Epidemics}

Epidemiological field surveys indicate that mass mortalities of apes and monkey species due to Ebola virus often appear at the end of the dry season (Pinzon et al. 2004), a period when food resources are scarce. Restricted access 


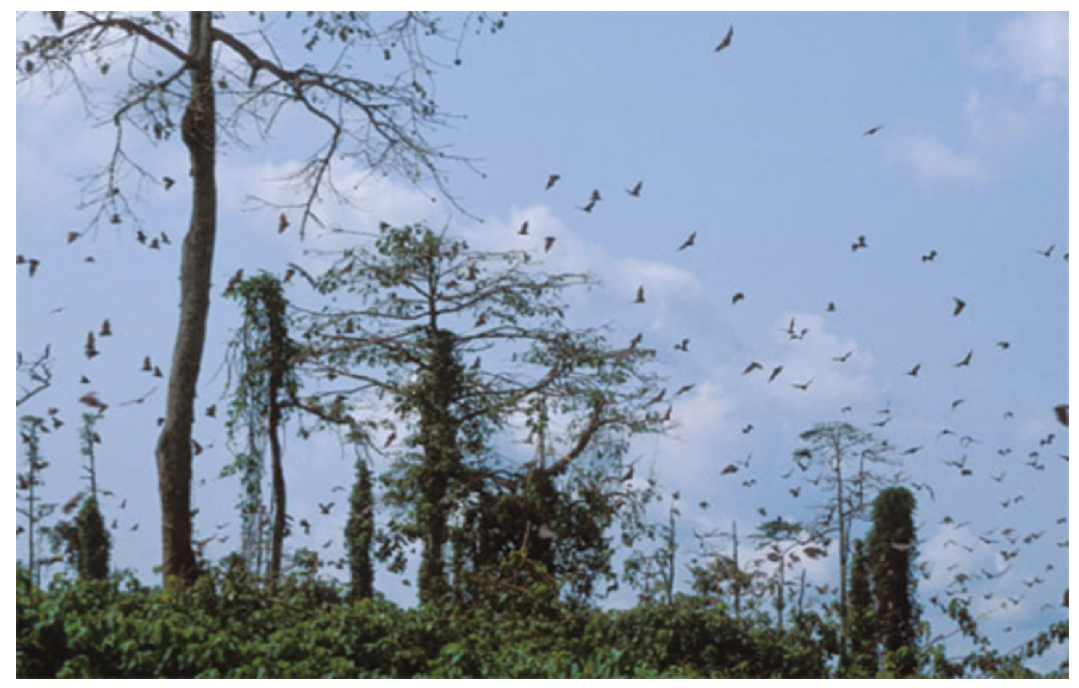

Fig. 5 Flight of fruit bats around the canopy trees of equatorial forest in Gabon. The fruit bats live and move in groups of several thousand individuals. This photograph illustrates the large number of contacts that can occur between the large primates and the bats gathered around the same tree to consume the fruits

to a limited number of fruit-bearing trees can lead to spatiotemporal clustering of diverse species of frugivorous animals, such as bats, nonhuman primates, and terrestrial species foraging on fallen or partially eaten fruits or spats. These dense aggregates of different species would increase the probability of contact between infected and susceptible individuals of both reservoir and secondary host species, and promote virus transmission (see the chapter by Real and Biek, this volume). The dry season aggregation of reservoir host species involved in natural maintenance cycles, augmented by incidentally infected secondary hosts serving as sources for intra- and interspecific transmission chains independent of repeated spillover from the reservoir host (see the chapter by Childs et al., this volume), provides an ecological setting for amplifying enzootic transmission of Ebola virus in a manner analogous to draught-induced amplification of enzootic Saint Louis encephalitis virus (SLEV), whereby arthropod vectors and vertebrate hosts are concentrated around a diminished number of water sources (Shaman et al. 2002).

Behavioral and physiological events occurring among bats during and subsequent to the tropical dry season serve to increase the contact rate and types of contacts between individual bats, which can promote transmission of Ebola 


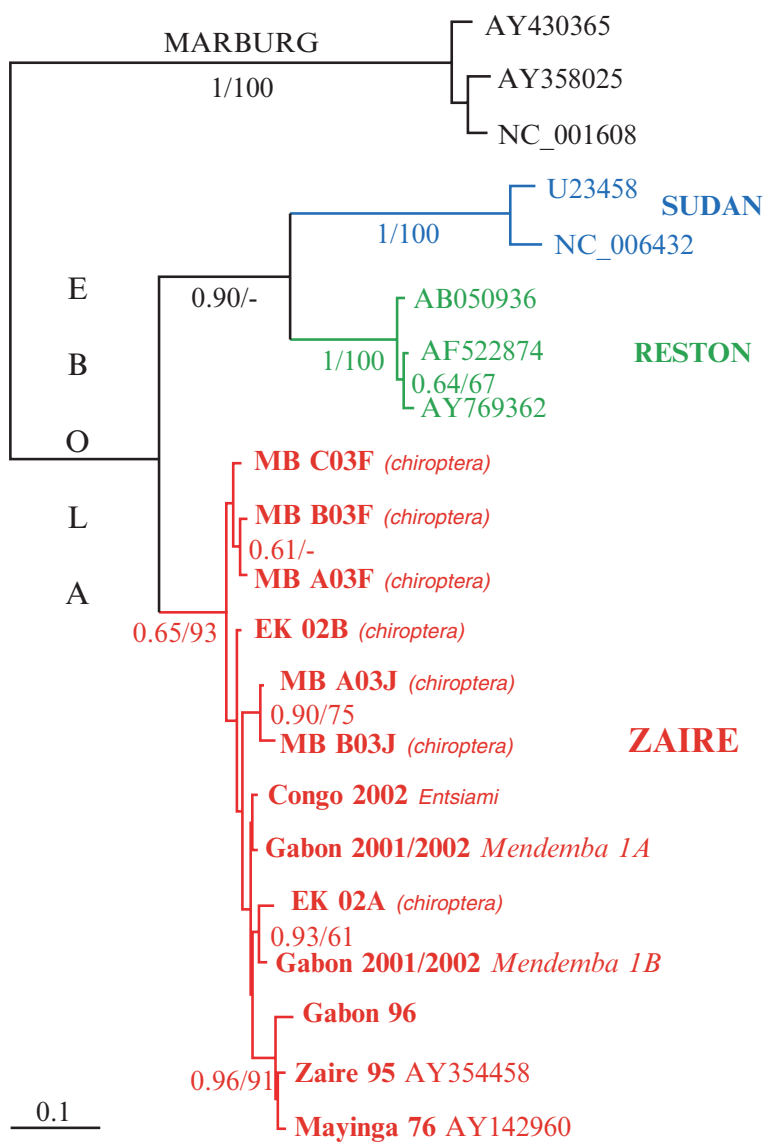

Fig. 6 Zaire Ebola virus sequences detected among fruit bats in Gabon and Republic of Congo. The values indicated below the branches are Bayesian posterior probabilities (left of the slash; values below 0.5 are not shown) and the maximum bootstrap percentages obtained with the parsimony method (right of the slash; values below less than $50 \%$ are not shown). The sequences obtained from bats are indicated as chiroptera (GenBank accession numbers Dq205409-15). The other sequences are viral sequences from symptomatic human cases

virus and increase $R_{0}$ (see the chapter by Real and Biek, this volume). In addition to increased competitive interactions driven by unusually high densities of individuals foraging for a common resource of limited availability, breeding activities of megachiropteran fruit bats can involve unusual social behavior as in the case of $H$. monstrosus, where aggregates of males (leks) compete collectively for 
the attention of females (Hill and Smith 1984); pregnancy can involve physiological changes among female bats that alter immune functions (Langevin and Barclay 1990). Parturition among the African megachiropteran bats occurs throughout the year, although seasonal peaks provide an ample amount of birthing fluids, blood, and placental tissues, potentially containing unusually high titers of Ebola virus, in a medium highly attractive and readily available to scavenging terrestrial mammals (Figs. 7,8).

\section{4}

\section{Other Members of the Filovirus Family}

The other two species of virus in the family Filoviridae are Marburg virus, which was once regarded as a subtype of African Ebola virus but is now known to be a distinct species, and the Reston subtype of Ebola, limited in distribution to the Philippines and perhaps other regions in southwestern Asia. The

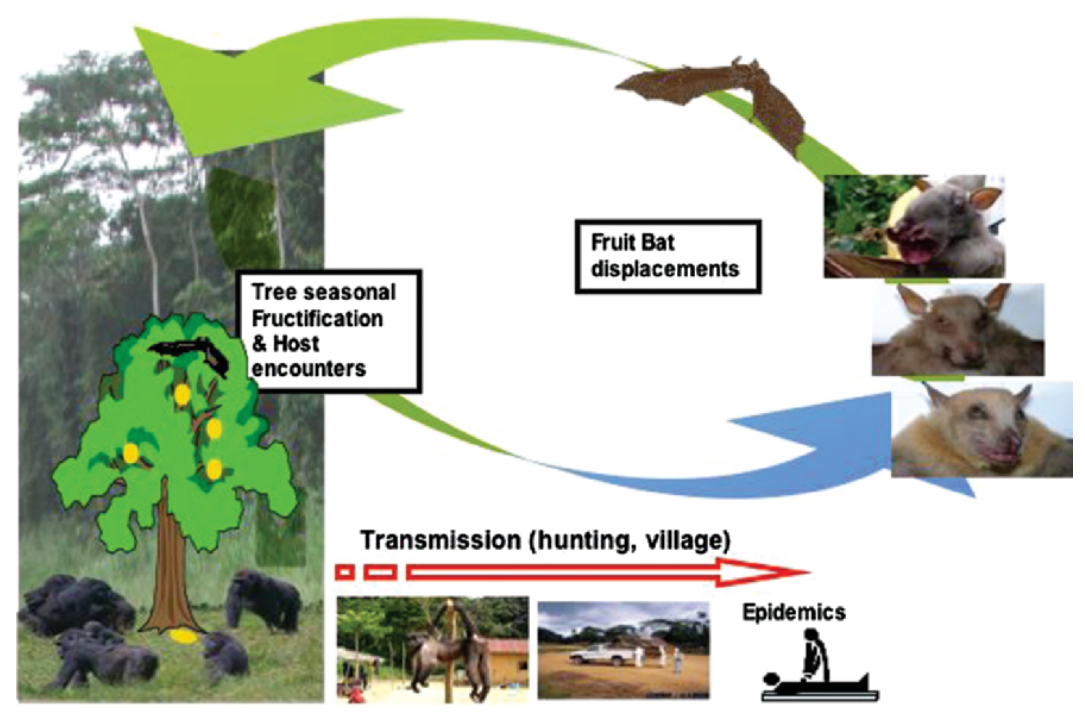

Fig.7 Hypothetical natural cycle in Central Africa of Ebola viruses. Fruit bats chronically infected with Ebola virus move to consume fruit in the canopy during the fruiting season of certain trees and throw masticated spats and fruit contaminated with Ebola virus-infected saliva. Large monkeys and forest duikers can become infected by eating these fruit and spats on the ground 


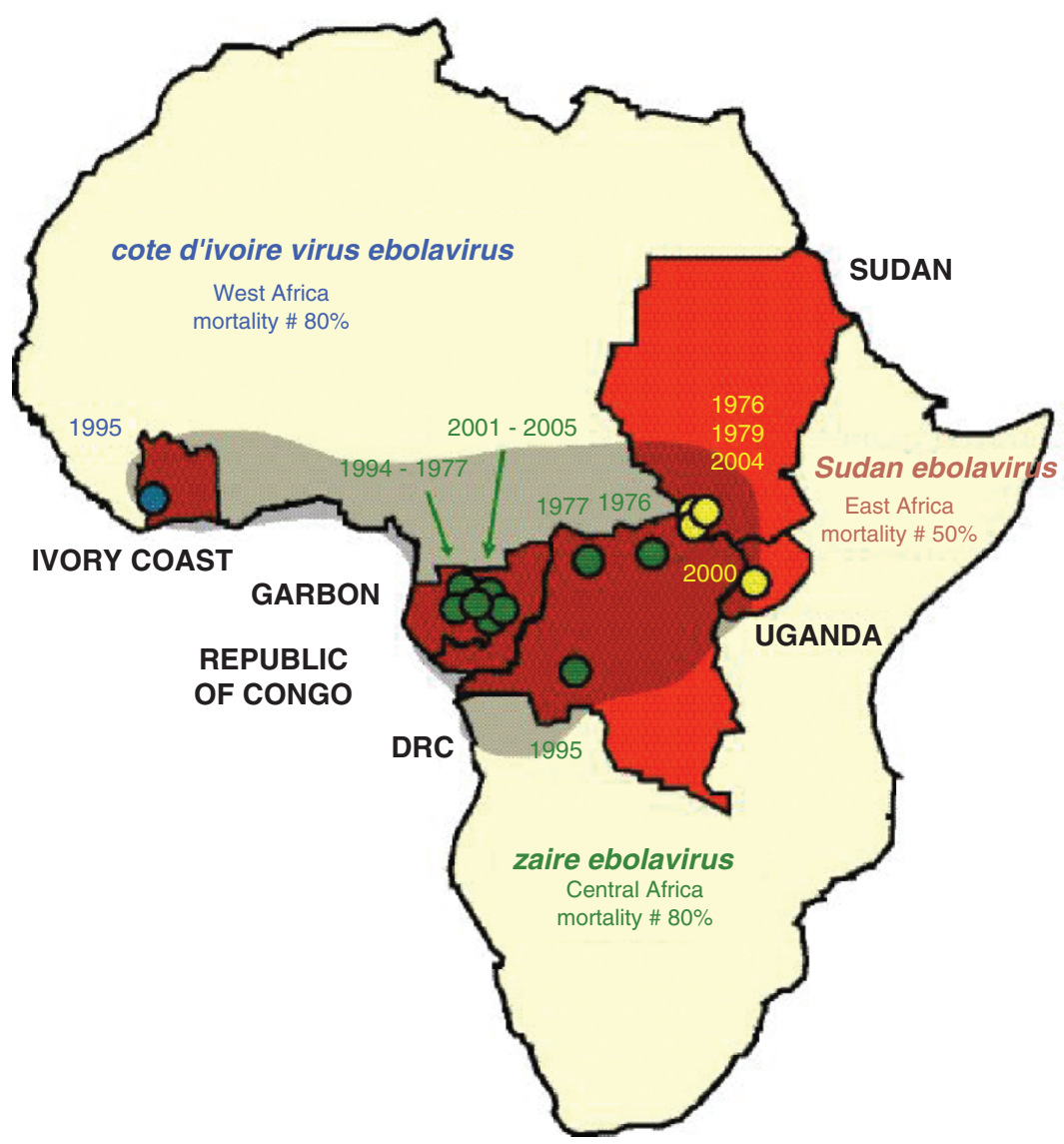

Fig. 8 Geographical distribution of the bat species believed to be potential reservoirs of Ebola virus subtypes and mortality rates of outbreaks due to different Ebola subtypes. The distribution area of bat species appears here in gray and represents the complete range of the three species implicated in Ebola virus transmission (see Fig. 4). The death rates of the different epidemics are interesting to note and pose the question of whether different species of bats are associated with each Ebola virus subtype

geographic distribution of Marburg virus is unknown, because knowledge has been restricted to investigations of the patchily distributed and rare outbreaks of human disease occurring in sub-Saharan Africa. The Ebola Reston subtype has been identified among primates in holding facilities in the Philippines and in countries receiving shipments of animals from this island nation. Based on 
the detection of specific antibodies present among a few humans involved in the care of infected monkeys, the Reston Ebola virus is capable of causing subclinical infection of humans.

\section{1}

\section{Marburg Virus}

The animal reservoir for Marburg virus remains unknown and few secondary hosts have been identified other than humans. The close relationship of Marburg virus to the African Ebola viruses suggests that bats may also be involved in natural maintenance cycles. Several epidemiological observations gleaned from the rare outbreaks of Marburg virus favor this hypothesis. Genetically distinct variants of Marburg virus were obtained during a "single" epidemic affecting gold miners working in mines inhabited by bats. The diversity of Marburg strains infecting these miners suggested multiple independent, but near simultaneous, spillover events requiring close human contact with a relatively common and accessible animal species serving as a reservoir host (Bausch et al. 2003). Although bats met these criteria, demonstration of Ebola virus infection through isolation or detection of viral sequences within tissues derived from field-collected bats or other wildlife has not been reported (Bertherat et al. 1999).

\section{2}

\section{The Phylogeographic Enigma of Reston Virus}

It is suggested that bats may also be the potential reservoir hosts for the subtypes Ebola-Sudan and Ebola-Ivory Coast, and possibly for the Ebola-Reston subtype. If bats serve as reservoir hosts for Ebola virus subtype Reston the species will necessarily be different than the three species of megachiropteran bats implicated as reservoir hosts for the Ebola-Zaire subtype, as the mammalian fauna of the Philippines is distinct from that of Africa, with many species indigenous only to certain islands comprising this nation.

The Reston subtype of Ebola virus is distinguished from the other Ebola subtypes both by its geographical separation and the pathophysiology of infections produced in humans and monkeys. It is the only filovirus found outside Africa, with all strains originating from the Philippines.

The first epidemics due to the Reston subtype among subhuman primates occurred between 1989 and 1990 in colonies of cynomolgus macaques (Macaca fascicularis) imported to three American quarantine facilities. The first epidemic was identified in a facility in Reston, Virginia (Geisbert et al. 1992; Jahrling et al. 1996), followed by facilities in Texas and Pennsylvania (Rollin et al. 1999; CDC 1996); all of the affected monkeys had been imported from the same 
primate breeding center in Manila, Philippines. An additional outbreak occurred in the Manila primate center in 1996, during which 383 of 1,404 macaques died and 85 were diagnosed positive for Ebola infection (Miranda et al. 1999).

The Reston strains induce a primarily respiratory pathology in the macaque, but they do not appear to be pathogenic for humans. A serologic study was carried out in 1990 on 186 animal technicians working in the Reston facility revealed the prevalence of antibody ranged between $6 \%$ and $67 \%$, depending on where the technicians worked in the holding facility. The presence of specific antibodies to the Reston Ebola virus and the discovery of high levels of antibodies in three technicians having worked near sick animals infected by Ebola virus-Reston, strongly suggest the occurrence of asymptomatic human infections. Four technicians developed a transitory viremia during this period, including a technician who cut his finger with a lancet during an autopsy on a sick monkey; no symptoms of disease were detected.

In spite of these geographical and pathophysiological differences, the structural and functional characteristics of Ebola-Reston are similar to the three other African Ebola subtypes. The genetic distances between the Reston subtype and the three African subtypes are similar, as are strains within subtypes. Beyond the considerable interest in the genetic basis for the phenotypic differences in the pathogenicity of Ebola-type viruses from Asia and Africa lies the biological mystery of the disjointed distribution of these viruses. Elucidating the evolutionary peregrinations and natural history of the Ebola viruses leading to the bizarre pattern of geographic distribution poses an ongoing biological challenge. Based on the genetic similarity among these viruses, it is reasonable to initially target the search for an animal reservoir host for Ebola-Reston among fruit bats in Asia belonging to the suborder Megachiroptera. In addition to identifying animal reservoir hosts within the Philippines, attempts to detect Ebola virus among species on the Asian mainland could provide clues to the origin of these unusual viruses.

\section{5}

\section{Conclusions}

5.1

\section{Bats, an Underappreciated Reservoir Host for Zoonotic Viruses}

Although bats are known to contribute to the epidemiology of a few other human pathogenic parasites (for example, the fungus, Histoplasma capsulatum, grows well in bat guano), there are many bat-borne viruses that present major concerns for human health (for review see Calisher et al. 2006). The 
Rhabdoviridae family, rabies virus, and rabies-related viruses in the genus Lyssavirus, are of obvious public health importance and include Mokola virus, Duvenhage virus, European bat lyssaviruses 1 and 2, and Australian bat lyssavirus. Lagos bat virus and four newly characterized lyssaviruses obtained from Eurasian Microchiroptera, Aravan, Khujand, and West Caucasian bat virus, have not yet been identified as causing human or animal disease (Kuzmin et al. 2003, 2005). Additionally, some viruses in the genus Flavivirus, including Japanese encephalitis virus and SLEV (reviewed by Sulkin and Allen 1974; Calisher et al. 2006), have been isolated from bats and are capable of causing epidemics of severe disease among humans and animals. However, of the more than 65 viruses isolated from bats and the numerous other viral infections identified solely on the basis of serological testing of bat sera, there exist few data to assess their risk to human health or to establish details of their maintenance ecology and the significance of bats as reservoir hosts (e.g., Dakar bat virus, Entebbe bat virus, Sokoluk virus, Yokose virus, Jugra virus, and Phnom Penh bat virus).

It is only recently that megachiropteran and microchiropteran bats have achieved notoriety as reservoir hosts of several newly described viruses capable of causing severe disease in humans and other animals. Various Pteropus spp. have been shown to be the reservoir hosts of Hendra and Nipah viruses, two novel viruses comprising the newly defined Henipavirus genus in the family Paramyxoviridae, which have caused severe disease among humans. Initially, Hendra and Nipah virus spillover was from the bat reservoir host to domestic livestock, horses and pigs, respectively, which served as the first secondary host in the transmission chain leading to human infection and disease (see the chapters by Childs et al. and Field et al., this volume). It was only after virus amplification and excretion via the respiratory route from infected livestock that human cases developed (see the chapter by Daniels et al., this volume), although Nipah virus transmission in Bangladesh appears to involve direct human infection from the bat reservoir host or from fruit contaminated by virus followed by human-to-human transmission (see the chapter by Field et al., this volume). In 2005, microchiropteran bats were identified as a reservoir host of the severe acute respiratory syndrome (SARS) coronavirus in Asia (Li et al. 2005). Of special note is the consistent association of bats with viruses containing negative-sense single-stranded RNA and belonging to the order Mononegavirales, lyssaviruses in the family Rhabdoviridae, henipaviruses viruses in the family Paramyxoviridae, and Ebola virus subtype Zaire in the family Filoviridae.

\section{2}

\section{Bats and Human Disease Emergence}

The concept of bats as reservoirs of emerging viral diseases of humans raises questions about an order of mammals for which much remains to be 
learned about their ecology, taxonomy, and their basic biology. In general, bats possess several unique features that make them notable reservoir hosts (reviewed in Calisher et al. 2006): their capacity to fly and range over long distances when feeding and, in some instances, when migrating; their capacity to entire torpor or hibernation; their tendency to cluster tightly in colonies that may number in the millions (Constantine et al. 1968) or establish large camps (see the chapter by Field et al., this volume); their population structure that can involve seasonal mixing of migratory and nonmigratory metapopulations presenting an opportunity for viral exchange; and the potential for infected bats to become chronic carriers of certain viruses that can be excreted over extended time periods (Sulkin and Allen 1974). Each of these attributes varies from species to species, in part depending on their specific environments.

Questions are arising today on the emergence of the Filoviridae within the general context of transmissible diseases of vertebrates. Of particular note is why it has taken more than 20 years to begin to understand the natural transmission cycles of Ebola virus, and why more than 30 years after the first epidemic of Marburg fever in Germany and Yugoslavia, does the animal reservoir for Marburg virus remain unknown? Several factors have hindered the pursuit of the elusive reservoir host for the filoviruses. Epidemics or sporadic cases of filovirus disease have most often occurred in remote locations in countries experiencing varying levels of social upheaval resulting from ongoing armed conflicts or the transient chaos that accompanies disease outbreaks of high mortality linked to hospital-associated transmission. Even at the best of times, the medical and public health infrastructure within central African nations is limited. Animal surveys initiated as a result of investigations into human epidemics have been opportunistic and have not been undertaken at the optimum place or time. Often the identification of a filovirus as the cause of a specific disease outbreak is delayed. Delay results in uncertainty when identifying the index case and, at best, complicates collection of a verbal patient history from surviving relatives or associates. Most animal surveys have biased collection over-representing terrestrial mammals as these species are accessible to trapping and can be purchased as bushmeat. Adequate sampling of bat species has mostly been limited to insectivorous microchiropterans (Liers et al. 1999), as obtaining bats feeding on fruits in the high canopy of trees within dense rainforests is difficult. Animal surveys conducted over short intervals during a single season will most often fail to sample species during critical time periods, such as at the end of the dry season, or when species may be physiologically and immunologically prone to virus infection or excretion, such as during mating and parturition. Finally, as previously mentioned, many surveys relied on technology for viral detection that was 
vastly inferior to the methods currently available, raising concerns about the reliability of diagnostic procedures of drastically reduced sensitivity.

\section{3}

\section{Intraspecies and Interspecies Contact and the Risk of Epidemic Initiation}

The probability for intra- and interspecific transmission of Ebola virus among species of bats and other wildlife will be influenced by ecological factors such as habitat preferences, roosting sites, and food habits, physiological factors such as age and reproductive status, and virological and immunological factors, such the genotypic and phenotypic variability among Ebola viruses and the potential for viral immunity or cross-immunity. Megachiropteran fruit bats can interact and expose other species to excreted Ebola virus through direct contact, such as inoculating virus present in saliva through bites, or indirect routes, as when discarding partially eaten fruit or spats contaminated with infectious virus. However, once spillover of Ebola virus has been achieved in an initial secondary host species, the emergence of human disease and an epidemic of Ebola hemorrhagic fever may require additional mediating events. If the initial secondary host is human, then a single spillover event may be sufficient to cause human disease, if the Ebola strain is virulent in that host, and the single diseased human may be sufficient to initiate an epidemic, if that individual is treated at a hospital and infects health providers. However, if the initial secondary case is a nonhuman primate or a duiker, then further multiplication of virus, either through repetitive spillover events or sustained transmission within the secondary host population (see the chapter by Childs et al., this volume), may be necessary to amplify the number of infected individuals within that host population such that a susceptible human contacts an infectious primate. Of course, a single infected human does not make an epidemic, but the factors prerequisite to the initiation of an epidemic are in play.

\section{4}

\section{Ebola Virus and Bats}

Knowledge of the natural history of Ebola virus has been clarified by the recent implication of fruit bats as reservoir hosts, and epidemiologic and virologic investigations have further elucidated the varied roles that humans and nonhuman primates and other wildlife can play in the several pathways leading to Ebola hemorrhagic fever emergence and resurgence. The distinction of wildlife species as incidental hosts, dying without further contribution to virus 
transmission, or significant initial secondary hosts, multiplying the number of infected and infectious individuals necessary to increase the probability that an individual susceptible human, a second secondary host species (see the chapter by Childs, this volume), will achieve contact and become infected by spillover, has provided sufficient details of potential routes of Ebola virus emergence that these elements can now be integrated into mathematical models to investigate transmission pathways.

The terrestrial vertebrates found infected with Ebola virus are highly susceptible to lethal infection and will not retransmit the virus back to the reservoir host $\left(\mathrm{H}_{\mathrm{R}}=\right.$ bats; see the chapter by Childs et al., this volume). Transmission leading to an epidemic/epizootic appears to be unidirectional, with the highly susceptible secondary hosts $\left(\mathrm{H}_{\mathrm{S1}}=\right.$ gorillas/chimpanzees $)$ being infected from a common source (directly from the $\mathrm{H}_{\mathrm{R}}$ or through contaminated biological products). Once infected, this $\mathrm{H}_{\mathrm{S} 1}$ can sustain transmission to infect additional secondary hosts through intraspecific contact, or transmit the virus to a second incidental host $\left(\mathrm{H}_{\mathrm{S} 2}\right)$ through interspecific contact (i.e., from primate to humans).

Such a transmission chain could lead to the wave-like spread of genetically related lineages of Ebola virus (Walsh et al. 2005) or, alternatively, explain outbreaks limited in time and space. Evidence accrued from epidemiological and molecular genetical studies of the genetic distance and phylogenetic origin of isolated strains will provide critical support for these competing hypotheses. Once humans become infected directly through contact with bats or materials contaminated with Ebola virus originating from bats, or, alternatively, through contact (i.e., butchering and consumption) with a previously infected $\mathrm{H}_{\mathrm{S1}}$, human-to-human transmission can be sustained for multiple generations.

Fruit bats have a preference for certain fruits that ripen at different times, through which they extract essential nutrients by chewing or sucking the pulp. Bats contaminate fruit with their saliva, potentially imparting any infectious virus present in their saliva, and the masticated fibrous waste or partially eaten fruit is deposited on the ground or left in the tree. As they feed, fruit bats also contaminate the ground with their urine and feces. The contaminated fruit or excreta on the ground or in the tree canopy can be consumed by mammals living in the tree canopy (Cercopithecus sp.) or by primates (i.e., gorillas, chimpanzees) or other terrestrial mammals (i.e., duikers) on the ground $\left(\mathrm{H}_{\mathrm{R}}{ }^{-}\right.$ to- $\mathrm{H}_{\mathrm{S} 1}$ transmission). Subsequent intraspecific $\left(\mathrm{H}_{\mathrm{S} 1}\right.$-to- $\left.\mathrm{H}_{\mathrm{S} 1}\right)$ or interspecific $\left(\mathrm{H}_{\mathrm{S1}}\right.$-to- $\left.\mathrm{H}_{\mathrm{S} 2}\right)$ transmission can occur through contact with infected blood, generally at the time of onset of clinically apparent symptoms within any secondary host species. It is also possible that humans might collect contaminated fruit from the trees or lying on the ground, as has reported with Nipah virus (see the chapter by Field et al., this volume). 


\section{5}

\section{Research Perspectives}

Several central questions remain to be addressed in order to understand the dynamics of intraspecific transmission within reservoir host populations and interspecific transmission affecting incidental and secondary hosts. It is essential that the pathogenesis of Ebola virus in the natural reservoir host be investigated to establish the incidence and prevalence of infection, the duration of infectiousness, the mechanisms of virus excretion, the potential for persistent infections to occur and evidence of sporadic shedding of infectious virus, and the influence of physiological or environmental factors (e.g., reproductive status, temperature, etc.) on the pattern of viral maintenance and transmission within $\mathrm{H}_{\mathrm{R}}$ populations.

With respect to investigating the role of bats as hosts of pathogens capable of causing diseases of humans and animals, a better understanding of the immune system of bats is critical to delineate responses to infection and to develop improved immunological reagents (see Calisher et al. 2006 for review).

Finally, the origin and evolution of filoviruses and their geographic spread remains totally unknown. The Asian Ebola virus clade hints at the ancient global spread of the Filovirus family, but the enigma posed by our current knowledge of filovirus distribution is begging for answers.

\section{References}

Allela L, Boury O, Pouillot R, Delicat A, Yaba P, Kumulungui B, Rouquet P, Gonzalez JP, Leroy EM (2005) Ebola virus antibody prevalence in dogs and human risk. Emerg Infect Dis 11:385-390

Amengual B, Whitby JE, King A, Cobo JS, Bourhy H (1997) Evolution of European bat lyssaviruses. J Gen Virol 78:2319-2328

Arata AA, Johnson B (1977) Approaches towards studies on potential reservoirs of viral haemorrhagic fever in southern Sudan. In: Pattyn SR (ed) Ebola virus haemorrhagic fever. Elsevier/Netherland biomedical, Amsterdam, pp 191-202

Badrane H, Tordo N (2001) Host switching in Lyssavirus history from the Chiroptera to the Carnivora orders. J Virol 75:8096-8104

Bausch DG, Borchert M, Grein T, Roth C, Swanepoel R, Libande ML, Talarmin A, Bertherat E, Muyembe-Tamfum JJ, Tugume B, Colebunders R, Konde KM, Pirad P, Olinda LL, Rodier GR, Campbell P, Tomori O, Ksiazek TG, Rollin PE (2003) Risk factors for Marburg hemorrhagic fever Democratic Republic of the Congo. Emerg Infect Dis 9:1531-1537

Bergmans W (1989) Taxonomy and biogeography of African fruit bats (Mammalia Megachiroptera). Beaufortia 39:89-152 
Bertherat E, Talarmin A, Zeller H (1999) La République Démocratique du Congo: Entre guerre civile et Virus de Marburg. Le Comité de Cooridantion Scienctifique et Technique International pour l'épideemie de Durba. Med Tropic 59:201-204

Breman JG, Johnson KM, van der Groen G, Robbins CB, Szczeniowski MV, Ruti K, Webb PA, Meier F, Heymann DL (1999) A search for Ebola virus in animals in the Democratic Republic of the Congo and Cameroon: ecologic, virologic, and serologic surveys, 1979-1980. J Infect Dis 179:S139-S147

Calisher CH, Childs JE, Field HE, Holmes KV, Schountz T (2006) Bats: important reservoir hosts of emerging viruses. Clin Microbiol Rev 19:531-545

Centers for Disease Control (1996) Ebola-Reston virus infection among quarantined nonhuman primates-Texas, 1996. Morb Mortal Wkly Rep 45:314-316

Constantine DG, Tierkel ES, Kleckner MD, Hawkins DM (1968) Rabies in New Mexico cavern bats. Pub Health Rep 83:303-316

Feldmann H, Wahl-Jensen V, Jones SM, Stroher U (2004) Ebola virus ecology: a continuing mystery. Trends Microbiol 12:433-437

Formenty P, Boesch C, Wyers M, Steiner C, Donati F, Dind F, Walker F, Le Guenno B (1999) Ebola virus outbreak among wild chimpanzees living in a rain forest of Cote d'Ivoire. J Infect Dis 179 [Suppl 1]:S120-S126

Geisbert TW, Jahrling PB, Hanes MA, Zack PM (1992) Association of Ebola-related Reston virus particles and antigen with tissue lesions of monkeys imported to the United States. J Comp Pathol 106:137-152

Gonzalez JP, McCormick JB, Saluzzo JF, Georges AJ (1983) Les fièvres hémorragiques africaines d'origine virale en République Centrafricaine. Cah ORSTOM Ser Ent Méd Parasit XXI:119-130

Gonzalez JP, Herbreteau V, Morvan J, Leroy EM (2005) Ebola virus circulation in Africa: a balance between clinical expression and epidemiological silence. Bull Soc Pathol Exot 98:210-217

Halpin K, Young PL, Field HE, Mackenzie JS (2000) Isolation of Hendra virus from pteropid bats: a natural reservoir of Hendra virus. J Gen Virol 81:1927-1932

Heymann DL, Weisfeld JS, Webb PA, Johnson KM, Cairns T, Berquist H (1980) Ebola hemorrhagic fever: Tandala 1977-1978. J Infect Dis 142:372-376

Hill JE, Smith JD (1984) Bats: a natural history. University of Texas Press, Austin

Huijbregts B, De Wachter P, Ndong Obiang S, Akou Ella M (2003) Ebola and the decline of gorilla Gorilla gorilla and chimpanzee Pan troglodytes populations in Minkebe forest, north-eastern Gabon. Oryx 37:437-443

Jahrling PB, Geisbert TW, Jaax NK, Hanes MA, Ksiazek TG, Peters CJ (1996) Experimental infection of cynomolgus macaques with Ebola-Reston filoviruses from the 1989-1990 US epizootic. Arch Virol Suppl 11:115-134

Johnson KM (1978) Ebola haemorrhagic fever in Zaire (1976) Bull World Health Organ $56: 271-293$

Kiley MP, Bowen ET, Eddy GA, Isaacson M, Johnson KM, McCormick JB, Murphy FA, Pattyn SR, Peters D, Prozesky OW, Regnery RL, Simpson DI, Slenczka W, Sureau P, van der Groen G, Webb PA, Wulff H (1982) Filoviridae: a taxonomic home for Marburg and Ebola viruses? Intervirology 18:24-32 
Kuzmin IV, Orciari LA, Arai YT, Smith JS, Hanlon CA, Kameoka Y, Rupprecht CE (2003) Bat lyssaviruses (Aravan and Khujand) from Central Asia: phylogenetic relationships according to N, P, G gene sequences. Virus Res 97:65-79

Kuzmin IV, Hughes GJ, Botvinkin AD, Orciari LA, Rupprecht CE (2005) Phylogenetic relationships of Irkut and West Caucasian bat viruses within the Lyssavirus genus and suggested quantitative criteria based on the $\mathrm{N}$ gene sequence for lyssavirus genotype definition. Virus Res 111:28-43

Langevin P, Barclay RMR (1990) Hypsignathus monstrosus. Mammal Species 357:1-4

Leirs H, Mills JN, Krebs JW, Childs JE, Akaibe D, Woollen N, Ludwig G, Peters CJ, Ksiazek TG (1999) Search for the Ebola virus reservoir in Kikwit Democratic Republic of the Congo: reflections on a vertebrate collection. J Infect Dis 179:S155-S163

Leroy EM, Rouquet P, Formenty P, Souquiere S, Kilbourne A, Froment JM, Bermejo M, Smit S, Karesh W, Swanepoel R, Zaki SR, Rollin PE (2004a) Multiple Ebola virus transmission events and rapid decline of central African wildlife. Science 303:387-390

Leroy EM, Telfer P, Kumulungui B, Yaba P, Rouquet P, Roques P, Gonzalez JP, Ksiazek TG, Rollin PE, Nerrienet E (2004b) A serological survey of Ebola virus infection in central African nonhuman primates. J Infect Dis 190:1895-1899

Leroy EM, Kumulungui B, Pourrut X, Rouquet P, Hassanin A, Yaba P, Delicat A, Paweska JT, Gonzalez JP, Swanepoel R (2005) Fruit bats as reservoirs of Ebola virus. Nature 438:575-576

Li W, Shi Z, Yu M, Ren W, Smith C, Epstein JH, Wang H, Crameri G, Hu Z, Zhang H, Zhang J, McEachern J, Field H, Daszak P, Eaton BT, Zhang S, Wang LF (2005) Bats are natural reservoirs of SARS-like coronaviruses. Science 310(5748):676-679

Mackenzie JS (2005) Emerging zoonotic encephalitis viruses: lessons from Southeast Asia and Oceania. J Neurovirol 1:434-440

Martini GA, Siegert R (1971) Marburg virus disease. Springer, Berlin Heidelberg New York, pp 131

Miranda ME, Ksiazek TG, Retuya TJ, Khan AS, Sanchez A, Fulhorst CF, Rollin PE, Calaor AB, Manalo DL, Roces MC, Dayrit MM, Peters CJ (1999) Epidemiology of Ebola (subtype Reston) virus in the Philippines, 1996. J Infect Dis 179 [Suppl 1]: S115-S119

Monath TP (1999) Ecology of Marburg and Ebola viruses: speculations and directions for the future research. J Infect Dis 179:S127-S138

Morvan JM, Deubel V, Gounon P, Nakoune E, Barriere P, Murri S, Perpete O, Selekon B, Coudrier D, Gautier-Hion A, Colyn M, Volehkov V (1999) Identification of Ebola virus sequences present as RNA or DNA in organs of terrestrial small mammals of the Central African Republic. Microbes Infect 1:1193-1201

Morvan JM, Nakoune E, Deubel V, Colyn M (2000) Forest ecosystems and Ebola virus. B Soc Pathol Exot 93:172-175

Pinzon JE, Wilson JM, Tucker CJ, Arthur R, Jahrling PB, Formenty P (2004) Trigger events: enviroclimatic coupling of Ebola hemorrhagic fever outbreaks. Am J Trop Med Hyg 71:664-674 
Pourrut X, Kumulungui B, Wittmann T, Moussavou G, Delicat A, Yaba P, Nkoghe D, Gonzalez JP, Leroy EM (2005) The natural History of Ebola virus in Africa. Microbes Infect 7:1005-1014

Reiter P, Turell M, Coleman R, Miller B, Maupin G, Liz J, Kuehne A, Barth J, Geisbert J, Dohm D, Glick J, Pecor J, Robbins R, Jahrling P, Peters C, Ksiazek T (1999) Field investigations of an outbreak of Ebola hemorrhagic fever Kikwit Democratic Republic of the Congo, 1995: arthropod studies. J Infect Dis 179:S148-S154

Rollin PE, Williams RJ, Bressler DS, Pearson S, Cottingham M, Pucak G, Sanchez A, Trappier SG, Peters RL, Greer PW, Zaki S, Demarcus T, Hendricks K, Kelley M, Simpson D, Geisbert TW, Jahrling PB, Peters CJ, Ksiazek TG (1999) Ebola (subtype Reston) virus among quarantined nonhuman primates recently imported from the Philippines to the United States. J Infect Dis 179 [Suppl 1]:S108-S114

Shaman J, Day JF, Stieglitz M (2002) Drought-induced amplification of Saint Louis encephalitis virus Florida. Emerg Infect Dis 8:575-580

Sulkin SE, Allen R (1974) Virus infections in bats. In: Melnick JL (ed) Monographs in Virolology 8. Karger, Basel

Swanepoel R, Leman PA, Burt FJ (1996) Experimental inoculation of plants and animals with Ebola virus. Emerg Infect Dis 2:321-325

Walsh PD, Abernethy KA, Bermejo M, Beyers R, De Wachter P, Akou ME, Huijbregts B, Mambounga DI, Toham AK, Kilbourn AM, Lahm SA, Latour S, Maisels F, Mbina C, Mihindou Y, Obiang SN, Effa EN, Starkey MP, Telfer P, Thibault M, Tutin CE, White LJ, Wilkie DS (2003) Catastrophic ape decline in western equatorial Africa. Nature 422:611-614

Walsh PD, Biek R, Real LA (2005) Wave-like spread of Ebola Zaire. PLoS Biol 3:e371

Yob JM, Field H, Rashdi AM, Morrissy C, van der Heide B, Rota P, bin Adzhar A, White J, Daniels P, Jamaluddin A, Ksiazek T (2001) Nipah virus infection in bats (order Chiroptera) in peninsular Malaysia. Emerg Infect Dis 7:439-441 